\title{
Voriconazole Therapeutic Drug Monitoring is Necessary for Children with Invasive Fungal Infection
}

\author{
Hyun Mi Kang, M.D.*, Soo Young Kang, M.D.*, Eun Young Cho, M.D.*. ${ }^{\dagger}$, \\ Kyung-Sang Yu, M.D., Ph.D. ${ }^{\ddagger}$, Ji Won Lee, M.D.*, ${ }^{\dagger} \|$, Hyoung Jin Kang, M.D., Ph.D.*, ${ }^{*}$, \\ Kyung Duk Park, M.D., Ph.D.*, ${ }^{*}$, Hee Young Shin, M.D., Ph.D.*, ${ }^{+}$, \\ Hyo Seop Ahn, M.D., Ph.D. ${ }^{\text {, } \|}$, Hyunju Lee, M.D., Ph.D. ${ }^{\jmath}{ }^{\dagger}$, \\ Eun Hwa Choi, M.D., Ph.D.* ${ }^{\dagger}$, and Hoan Jong Lee, M.D., Ph.D.* ${ }^{\dagger}$ \\ Department of Pediatrics ${ }^{*}$, Seoul National University Children's Hospital, Seoul, Republic of Korea \\ Department of Pediatrics ${ }^{\dagger}$, Seoul National University College of Medicine, Seoul, Republic of Korea \\ Department of Clinical Pharmacology and Therapeutics ${ }^{\ddagger}$, Seoul National University College of Medicine, \\ Seoul, Republic of Korea \\ Department of Pediatrics ${ }^{\mathcal{S}}$, Seoul National University Bundang Hospital, Gyeonggi-do, Republic of \\ Korea \\ Cancer Research Institute", Seoul National University College of Medicine, Republic of Korea
}

Purpose: To determine the clinical significance of voriconazole therapeutic drug monitoring (TDM) in the pediatric population. Methods: Twenty-eight patients with invasive fungal infections administered with voriconazole from July 2010 to June 2012 were investigated retrospectively. Fourteen received TDM, and 143 trough concentrations were analyzed. All 28 patients were assessed for adverse events and treatment response six weeks into treatment, and at the end.

Results: Out of 143 samples, $53.1 \%$ were within therapeutic range (1.0-5.5 mg/L). Patients administered with the same loading ( $6 \mathrm{mg} / \mathrm{kg} / \mathrm{dose}$ ) and maintenance (4 mg/ $\mathrm{kg} /$ dose) dosages prior to initial TDM showed highly variable drug levels. Adverse events occurred in 9 of 14 patients (64.3\%) in both the TDM and non-TDM group. In the TDM group, voriconazole-related encephalopathy $(n=2,14.3 \%)$ and aspartate aminotransferase (AST) or alanine aminotransferase (ALT) elevation ( $n=8,57.1$ $\%)$ occurred with serum levels in the toxic range $(>5.5 \mathrm{mg} / \mathrm{L})$, whereas blurred-vision $(\mathrm{n}=2,14.3 \%)$ occurred within the therapeutic range $(1.18 \mathrm{mg} / \mathrm{L}$ and $3.9 \mathrm{mg} / \mathrm{L})$. The frequency of voriconazole discontinuation due to adverse events was lower in the TDM group ( $0.0 \%$ vs. $18.2 \%, P=0.481)$. Overall, $57.2 \%$ of the patients in the TDM group versus $14.3 \%$ in the non-TDM group showed clinical response after 6 weeks $(P=0.055)$, whereas $21.4 \%$ in the TDM group versus $14.3 \%$ in the non-TDM group showed response at final outcome $(P=0.664)$. In the TDM group, $>67.0 \%$ of the serum levels were within therapeutic range for the first 6 weeks; however $45.5 \%$ were within therapeutic range for the entire duration. Conclusion: Routine TDM is recommended for optimizing the therapeutic effects of voriconazole.

Key Words: Therapeutic drug monitoring, Voriconazole, Child, Invasive aspergillosis, Invasive fungal infection

Received: 8 August 2013, Revised: 13 October 2013

Accepted: 15 October 2013

Correspondence: Eun Young Cho, M.D.

Department of Pediatrics, Seoul National University Children's

Hospital, Republic of Korea

Tel: 02)2072-3624, Fax: 02)766-7283

E-mail: pedeyc@gmail.com

\section{Introduction}

Invasive fungal infections (IFI) are among the most important causes of morbidity and mortality 
in immunocompromised patients. With advances in treatment options for hematologic malignancies, the clinical outcome of immunocompromised patients has improved, resulting in an increasing number of patients living with a profoundly compromised immune system. One of the sequelae to such phenomenon is the increase in the incidence of IFI over the past decade ${ }^{1,2)}$. Because of the seriousness of the disease and its fatal outcome, IFI has become an eminent obstacle in the outcome of immunocompromised patients.

Novel agents are continually being discovered targeting fungal infections ${ }^{3)}$. It has been reported that in patients with invasive aspergillosis, initial therapy with voriconazole compared to amphotericin B led to better outcome and improved survival ${ }^{4)}$. Therefore, voriconazole is now being used extensively in patients with $\mathrm{IFI}^{5)}$.

Voriconazole is a second generation triazole with broad spectrum of antifungal activity, indicated for use in the treatment of invasive aspergillosis, candidiasis, as well as other $\mathrm{IF}^{6}{ }^{6)}$. It is known to reach steady-state concentrations after $5-7$ days, but can be reduced to $1-2$ days by starting with a loading $\operatorname{dose}^{7)}$. Indicated in both adults and children, voriconazole is known to have non-linear pharmacokinetics in adults. Many studies have demonstrated that pharmacokinetics of voriconazole in children are different from that of adults; while some studies demonstrate linear plasma pharmacokinetics ${ }^{8,9)}$, other studies show that children have high interpatient variability which limits the accurate prediction of pediatric voriconazole exposure based on adult dosages ${ }^{10)}$.

The high morbidity and mortality of IFI warrants aggressive yet specified treatment, and because voriconazole has a narrow therapeutic margin and unpredictable serum levels, the awareness for therapeutic drug monitoring (TDM) is increasing. This study aimed to determine the implications of voriconazole TDM on the clinical outcome and adverse events in pediatric immunocompromised patients.

\section{Materials and Methods}

\section{Patients}

We reviewed the medical records at Seoul $\mathrm{Na}^{-}$ tional University Children's Hospital (SNUCH), a tertiary care, 350-bed pediatric referral hospital with an electronic medical record system. This was a retrospective study on pediatric patients with hemato-oncologic disease or immunosuppression, who were administered voriconazole. Voriconazole became available at SNUCH in July of 2005, and from July 2005 to June 2012 a total of 57 pediatric patients were administered voriconazole. Voriconazole TDM became available as a clinical study in November 2008, and was performed on pediatric patients starting July 2010.

Between July 2010 and June 2012, a total of twenty-eight patients aged 18-years old or younger were included in this study. All patients who received voriconazole at least once for treatment or prophylaxis of IFI were included. Fourteen patients underwent voriconazole serum level monitoring, and a total of 143 serum trough concentrations were analyzed. All 28 patients administered with voriconazole were assessed for voriconazole-related adverse events and treatment response six weeks into treatment, and at final outcome. 


\section{Investigations for diagnosis of fungal infection}

Patients fulfilling one of the 'host factors' of the revised version of the Invasive Fungal Infection Group of the European Organization for Research and Treatment of Cancer and Mycosis study Group (EORTC/MSG) criteria' ${ }^{5)}$ were assumed to be at high risk for invasive fungal disease and were checked for vital signs daily and screened with Aspergillus galactomannan (Platelia Aspergillus; Bio-Rad Laboratories, United States) weekly. The threshold optical density index (ODI) of Aspergillus galactomannan was set as 0.5 according to the pediatric infection specialists at our hospital. A CT scan of the lung was performed when patients remained febrile for 5 days despite broad-spectrum antibiotics, when an abnormal shadow emerged on routine chest Xray examinations, or when Aspergillus galactomannan titers became positive.

IFI and responses to antifungal therapy were classified by definitions of the European Organization for Research and Treatment of Cancer/Mycoses Study Group (EORTC/MSG) ${ }^{11)}$.

\section{Drug administration}

Of the 28 patients that received voriconazole administration, 18 patients received voriconazole intravenously (6 in the TDM group and 12 in the nonTDM group) and 10 patients received voriconazole intravenously and then switched to the oral form (8 in the TDM group and 2 in the non-TDM group). Reasons for the switch from intravenous to oral form was mainly due to fluid restriction, difficulty of intravenous line access, and discharge from the ward.

Patients received two loading doses of $6 \mathrm{mg} / \mathrm{kg} /$ dose and maintenance doses of $4 \mathrm{mg} / \mathrm{kg} / \mathrm{dose}$. In the TDM group, 3 patients did not receive loading doses, whereas in the non-TDM group, 1 patient did not receive loading doses. Patients in the TDM group received dosage adjustment after the initial TDM sampling if the levels were below or above the therapeutic level, and the next TDM sampling occurred 7 days after adjustments were made.

\section{Measurement of voriconazole level}

A quantitative analysis of voriconazole was performed using high-performance liquid chromatography (1200 series, Agilent Technologies, United States) coupled with tandem mass spectrometry (API3200, Applied Biosystems/MDS sciex, United States). Trough levels were measured by obtaining blood samples 30 minutes before the next scheduled dosing of voriconazole. The therapeutic range was determined as $1.0-5.5 \mathrm{mg} / \mathrm{L}^{9,12,13)}$.

\section{Adverse events}

Adverse events and their relationship with voriconazole were defined according to the criteria of the National Cancer Institute ${ }^{14)}$, where a voriconazole-related adverse event was defined as one with a possible or stronger relationship. Encephalopathy included altered mental state, hallucinations, and seizures. Patients with light sensitivity, blurring, or changes in color vision were defined as having visual changes. Aspartate aminotransferase (AST) or alanine aminotransferase (ALT) of greater than 5fold compared to baseline levels taken before initiating voriconazole therapy was considered abnormal. Other known voriconazole-related adverse events (i.e., hypertension, arrhythmia, nausea, vomiting, abdominal pain, pancytopenia, acute renal failure, hypocalcaemia, and rash) ${ }^{15)}$ were investigated in each 
patient, but their relationship with voriconazole did not meet the possible or stronger relationship criteria.

\section{Treatment response}

Treatment response was categorized as according to the general criteria for global responses to antifungal therapy according to the EORTC/MSG criteria 11). Treatment success was considered in patients with complete or partial response. A complete response was defined as resolution of all attributable symptoms and signs of disease and radiological abnormalities, and mycological evidence of eradication of disease. A partial response was defined as improvement in attributable symptoms and signs of disease and radiological abnormalities, and evidence of clearance of cultures or reduction of fungal burden. Treatment failure was considered in patients with stable response, progression of disease, or death. A stable response was defined as minor or no improvement in fungal disease, but no evidence of progression. Progression of fungal disease was defined as clinical, radiologic, and mycological progression. Death included any death during the period of evaluation, regardless of attribution.

Patients who received voriconazole for prophylaxis of fungal infection, and those who discontinued voriconazole before 6 weeks were categorized into the 'unable to determine outcome' group.

The outcome of IFI was assessed at 6 weeks after beginning voriconazole therapy and at final outcome. Six weeks was chosen for outcome assessment because in invasive aspergillosis, clinical response to therapy may be evident by $2-6$ weeks ${ }^{16)}$.

\section{Statistical analysis}

In order to compare categorical variables for ba- seline characteristics, Fisher's exact test, Pearson Chi square test, and Mann-Whitney $U$ test was used. For adverse events and treatment outcome, the Fisher's exact test was used. Statistical analyses were performed using SPSS (Statistical Package for the Social Sciences) software (ver. 19.0; IBM Corp., Unites States). All tests were 2 -tailed. A $P$ value $<0.05$ was considered statistically significant.

\section{Ethics statement}

The study protocol was approved by the institutional review board of Seoul National University Hospital (IRB registration number-H-1204-040405). Informed consent was exempted, since the study was conducted in a retrospective manner, and also since the patients' personal information was not exposed.

\section{Results}

\section{Baseline patient characteristics}

Between July 2010 and June 2012, a total of 28 patients with hemato-oncologic disease or immunosuppression (26 patients; 15 patients who received hematopoietic stem cell transplantation, 2 acute myelocytic leukemia patients, 5 acute lymphocytic leukemia patients, 2 aplastic anemia patients, and 2 solid tumor patients), congenital neutropenia (1 patient), and juvenile rheumatoid arthritis on steroid therapy (1 patient) were administered with voriconazole during this period. Six patients had proven IFI (4 patients with invasive aspergillosis, 1 patient with mucormycosis, and 1 patient with invasive candidiasis), 13 patients had probable IFI (all 13 patients with invasive aspergillosis), 4 patients had possible IFI, and 5 patients were prophylactically administered 
Table 1. Baseline Characteristics of the Patients who Received Voriconazole Treatment for Invasive Fungal Infection

\begin{tabular}{|c|c|c|c|}
\hline & \multicolumn{2}{|c|}{ No. of cases $(\%)$} & \multirow{2}{*}{$P$} \\
\hline & $\mathrm{TDM}(\mathrm{n}=14)$ & Non-TDM $(n=14)$ & \\
\hline Median age, years (range) & $12.8(0.6-15.9)$ & $13.4(0.4-18.7)$ & $1.000^{\ddagger}$ \\
\hline Sex, male & $10(71.4)$ & $11(78.6)$ & $1.000^{\dagger}$ \\
\hline Underlying disease & & & $0.185^{*}$ \\
\hline Hematopoietic stem cell transplantation & $6(42.9)$ & $9(64.3)$ & \\
\hline Acute myelocytic leukemia & $1(7.1)$ & $1(7.1)$ & \\
\hline Acute lymphoblastic leukemia & $2(14.3)$ & $3(21.4)$ & \\
\hline Aplastic anemia & $2(14.3)$ & $0(0.0)$ & \\
\hline Solid tumor & $2(14.3)$ & $0(0.0)$ & \\
\hline Congenital neutropenia & $1(7.1)$ & $0(0.0)$ & \\
\hline Juvenile rheumatoid arthritis on steroid therapy & $0(0.0)$ & $1(7.1)$ & \\
\hline Neutropenia $(\mathrm{WBC}<500 / \mu \mathrm{L})$ & $9(64.3)$ & $8(57.1)$ & $1.000^{\dagger}$ \\
\hline Evidence of $\mathrm{IFI}^{S}$ & & & $0.815^{*}$ \\
\hline Proven & $4(28.6)$ & $2(14.3)$ & \\
\hline Probable & $6(42.9)$ & $7(50.0)$ & \\
\hline Possible & $2(14.3)$ & $2(14.3)$ & \\
\hline Prophylaxis & $2(14.3)$ & $3(21.4)$ & \\
\hline Site of infection & & & $0.683^{*}$ \\
\hline Lung & $6(42.9)$ & $6(42.9)$ & \\
\hline Sinus & $1(7.1)$ & $0(0.0)$ & \\
\hline Intra-abdominal & $0(0.0)$ & $1(7.1)$ & \\
\hline Multiorgan/Disseminated & $4(28.6)$ & $3(21.4)$ & \\
\hline Unknown $\|$ & $3(21.4)$ & $4(28.6)$ & \\
\hline Fungal organisms & & & $0.238^{*}$ \\
\hline Aspergillus & $12(85.7)$ & $9(64.3)$ & \\
\hline Candida & $1(7.1)$ & $0(0.0)$ & \\
\hline Mucorales & $0(0.0)$ & $1(7.1)$ & \\
\hline Unknown" & $1(7.1)$ & $4(28.6)$ & \\
\hline Reason for voriconazole use & & & $0.693^{*}$ \\
\hline First-line use & $2(14.3)$ & $1(7.1)$ & \\
\hline Failure of other antifungal agent & $9(64.3)$ & $11(78.6)$ & \\
\hline Combination therapy & $3(21.4)$ & $2(14.3)$ & \\
\hline Duration of voriconazole use, days (median) (IQR) & $57.50(24.00-143.00)$ & $13.50(6.00-40.00)$ & $0.009^{\ddagger}$ \\
\hline
\end{tabular}

Abbreviations: TDM, therapeutic drug monitoring; IFI, invasive fungal infection.

*Pearson Chi square test.

${ }^{\dagger}$ Fisher's exact test.

${ }^{\ddagger}$ Mann-Whitney U test.

${ }^{5}$ Evidence of IFI according to the EORTC/MSG criteria.

"Unknown due to Aspergillus galactomannan antigen positive or prophylactic use.

"Combination with either Caspofungin or Amphotericin B.

with voriconazole. Of the 28 patients, $14(50.0 \%)$ received voriconazole TDM, and a total of 143 trough concentrations were measured.

Table 1 shows the characteristics of the patients included in this study. The baseline characteristics of the patients showed no significant statistical difference between the TDM and non-TDM groups, except the median duration of treatment (57.5 days in the TDM group versus 13.5 days in the non-TDM group, $P=0.009)$. 


\section{Results of voriconazole TDM}

\section{1) Intra-individual variability}

A total of 143 serum trough concentrations were taken from 14 patients (median 7.5 samples per patients, with the range at 1 to 32$)$. With the therapeutic range set at $1.0-5.5 \mathrm{mg} / \mathrm{L}, 18(12.6 \%)$ of the samples were in the toxic range $(>5.5 \mathrm{mg} / \mathrm{L}), 49$ $(34.3 \%)$ were below therapeutic range $(<1.0 \mathrm{mg} / \mathrm{L})$, leaving 76 (53.1\%) within therapeutic range. Maintenance voriconazole dosages for toxic, therapeutic, and below therapeutic levels were $4.0-11.0 \mathrm{mg} / \mathrm{kg} /$ dose, $3.5-11.0 \mathrm{mg} / \mathrm{kg} / \mathrm{dose}$, and $3.0-10.0 \mathrm{mg} / \mathrm{kg} /$ dose, respectively. Fig. 1 shows large fluctuations

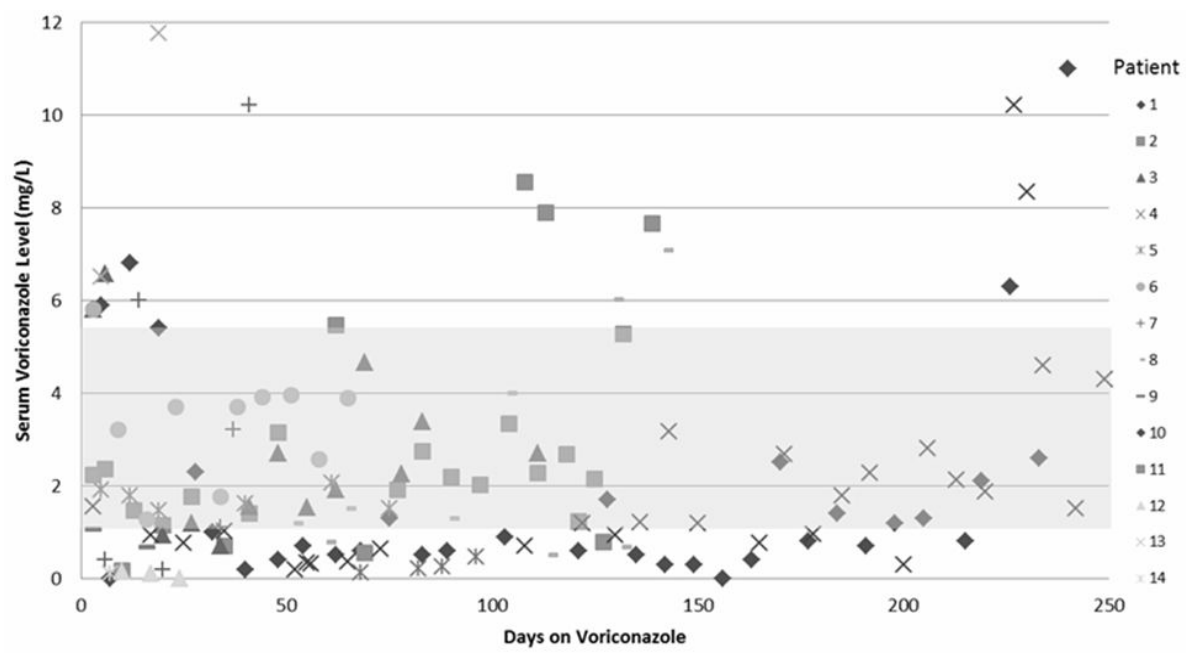

Fig. 1. Distribution of 143 voriconazole serum trough levels from 14 patients. With the therapeutic range set at 1.0-5.5 mg/L, $18(12.6 \%)$ samples were in the toxic range $(>5.5 \mathrm{mg} / \mathrm{L}), 49$ (34.3\%) samples were below therapeutic range $(<1.0$ $\mathrm{mg} / \mathrm{L})$, leaving $76(53.1 \%)$ samples within therapeutic range.

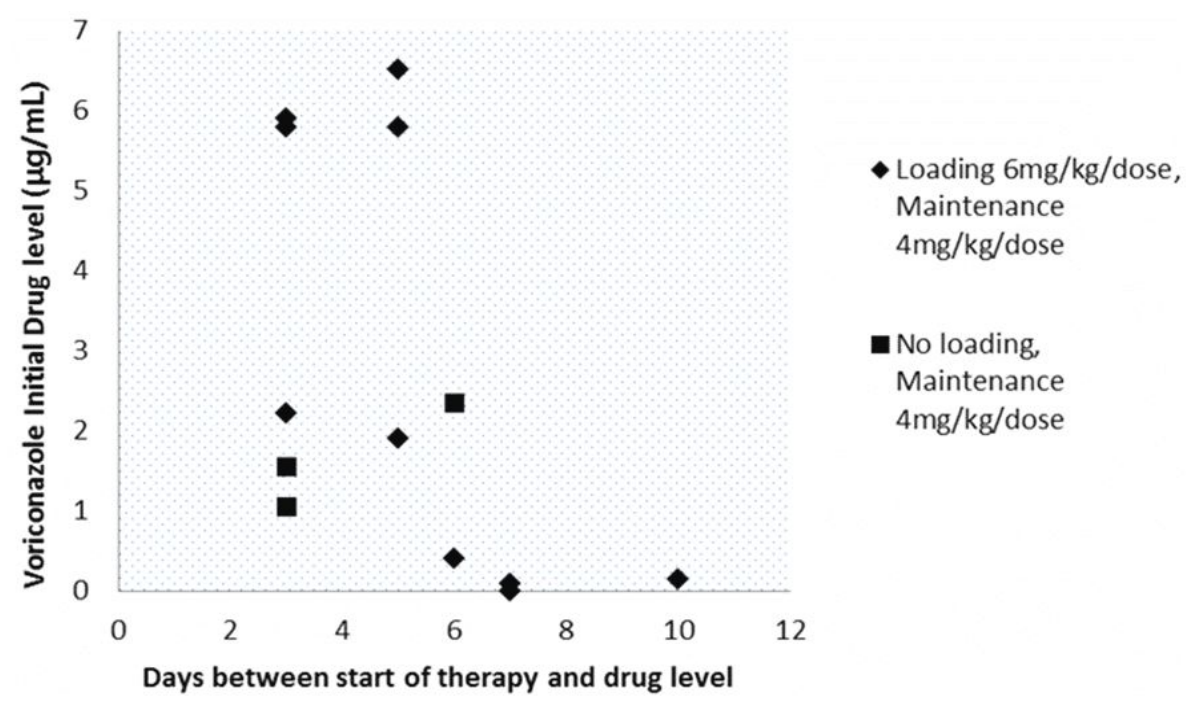

Fig. 2. The initial voriconazole concentration of 13 patients and the day it was taken after initiation of the drug. One patient's initial voriconazole concentration was taken 52 days after initiation of therapy therefore is not included in the graph. 
of serum voriconazole levels within one patient during treatment.

\section{2) Inter-individual variability}

Fig. 2 shows the day and concentration of the first voriconazole serum level taken from patients after the initiation of voriconazole treatment. One patient's initial voriconazole concentration was taken 52 days after starting therapy, therefore is not included in the graph. Patients who were administered with identical loading dosages of $6 \mathrm{mg} / \mathrm{kg} / \mathrm{dose}$ and maintenance dosages of $4 \mathrm{mg} / \mathrm{kg} / \mathrm{dose}$ or no loading doses and only maintenance doses of $4 \mathrm{mg} / \mathrm{kg} / \mathrm{dose}$ had greatly varying serum concentrations, demonstrating inter-individual variability.

\section{Adverse events during voriconazole use}

Nine out of 14 patients (64.3\%) in both the TDM and non-TDM group experienced adverse events (Table 2). In both groups, 8 out of 14 patients (57.1 $\%$ ) experienced AST or ALT elevation greater than 5 -fold of their baseline levels measured prior to initiating voriconazole. Two patients $(14.3 \%)$ in the TDM group and one patient $(7.1 \%)$ in the non-TDM group displayed voriconazole-related encephalopathy.
Two patients (14.3\%) in the TDM group complained of blurred vision during treatment, whereas none of the patients in the non-TDM group had visual symptoms.

Even though patients in both the TDM and nonTDM group experienced similar percentages of voriconazole-related adverse events, none of the patients in the TDM group discontinued the drug because of its side effects, whereas 2 patients $(18.2 \%)$ in the non-TDM group were withdrawn from voriconazole treatment because of the side effects $(P=0.481)$.

Patients in the TDM group were analyzed to observe how adverse events correlated with toxic drug levels. The two patients with voriconazole-related encephalopathy displayed their symptoms while serum levels were in the toxic range. One patient developed symptoms of encephalopathy on the $23^{\text {rd }}$ day of treatment, after serum voriconazole levels maintained in the toxic range for the first 20 days of treatment, peaking up to $6.57 \mathrm{mg} / \mathrm{L}$. The other patient with voriconazole-related encephalopathy had serum voriconazole levels in the toxic range for the first 19 days of treatment, peaking up to 11.75 $\mathrm{mg} / \mathrm{L}$ before presenting symptoms of encephalopathy.

Table 2. Drug Adverse Events during Voriconazole Use

\begin{tabular}{|c|c|c|c|}
\hline & \multicolumn{2}{|c|}{ No. of cases (\%) } & \multirow{2}{*}{$P^{*}$} \\
\hline & $\mathrm{TDM}(\mathrm{n}=14)$ & Non-TDM $(n=14)$ & \\
\hline Any adverse drug event & $9(64.3)$ & $9(64.3)$ & 1.000 \\
\hline Drug discontinuation due to adverse events & $0(0.0)$ & $2\left(18.2^{\dagger}\right)$ & 0.481 \\
\hline \multicolumn{4}{|l|}{ Adverse drug event } \\
\hline Liver function test abnormality ${ }^{\ddagger}$ & $8(57.1)$ & $8(57.1)$ & 1.000 \\
\hline Encephalopathy $^{s}$ & $2(14.3)$ & $1(7.1)$ & 1.000 \\
\hline Visual changes $\|$ & $2(14.3)$ & $0(0.0)$ & 0.481 \\
\hline
\end{tabular}

"Fisher's exact test

${ }^{\dagger}$ Out of $\mathrm{n}=11$ (the total number of patients with adverse drug event)

${ }^{\ddagger}$ Aspartate aminotransferase or alanine aminotransferase levels increase greater than 5-fold the baseline

${ }^{5}$ Including altered mentality, hallucinations, seizures

"Including light sensitivity, blurring, or changes in color vision 
Blurred vision occurred in two patients in the TDM group, and both patients had serum levels within the therapeutic range $(1.18 \mathrm{mg} / \mathrm{L}$ and $3.9 \mathrm{mg} / \mathrm{L})$ when the symptoms presented. Eight patients in the TDM group had liver enzyme elevation. With the exception of two patients whose serum voriconazole level maintained within the therapeutic or sub-therapeutic range during the entire treatment duration, 6 patients' voriconazole level was in the toxic range greater than 10 treatment days. Of these 6 patients, 4 had serum levels in the toxic range prior to AST or ALT elevation, whereas the other two patients' AST or ALT started to rise just before serum voriconazole levels measured in the toxic range.

\section{Outcome between TDM and non-TDM group}

To observe differences in the outcome between the TDM and non-TDM group, patients were assessed at 6 weeks after initiating voriconazole, and at final outcome (Table 3). Of the 14 patients that did not receive TDM, two (14.3\%) showed treatment success at 6 weeks, whereas treatment failure occurred in 6 patients $(42.8 \%)$. The remaining 6 patients $(42.8 \%)$ received voriconazole for prophy- laxis or did not receive a full 6 week treatment. In the TDM group, 8 patients $(57.2 \%)$ showed treatment success at 6 weeks after initiating voriconazole, which is comparable to the response shown in the non-TDM group $(P=0.055)$. Three patients (21.4\%) in the TDM group experienced treatment failure, and the remaining 3 patients' (21.4\%) outcome was not evaluated due to either prophylactic use or early cessation of treatment.

By final outcome, 2 patients (14.3\%) in the nonTDM group and 3 (21.4\%) in the TDM group showed treatment success, with no statistically significant difference in the end result between the two groups $(P=0.664)$.

Excluding the 3 patients whose outcome was not evaluated due to either prophylactic use or early cessation of treatment, a total of 11 patients were evaluated to see how drug levels affected their outcome. The 11 patients were able to maintain their serum voriconzole levels within therapeutic range $67.0 \%$ of the time for the first 6 weeks; however by the end of treatment, $45.5 \%$ of their serum voriconzole levels were within therapeutic.

Table 3. Outcome at 6 Weeks and Final Outcome of the Patients Received Voriconazole Treatment for Invasive Fungal Infection

\begin{tabular}{|c|c|c|c|}
\hline & \multicolumn{2}{|c|}{ No. of cases $(\%)$} & \multirow{2}{*}{$P^{*}$} \\
\hline & TDM $(n=14)$ & Non-TDM $(n=14)$ & \\
\hline Response at 6 weeks & & & 0.055 \\
\hline Treatment success & $8(57.2)$ & $2(14.3)$ & \\
\hline Treatment failure & $3(21.4)$ & $6(42.8)$ & \\
\hline Unable to determine outcome ${ }^{\dagger}$ & $3(21.4)$ & $6(42.8)$ & \\
\hline Response the end of treatment & & & 0.664 \\
\hline Treatment success & $3(21.4)$ & $2(14.3)$ & \\
\hline Treatment failure & $8(57.2)$ & $6(42.8)$ & \\
\hline Unable to determine outcome ${ }^{\dagger}$ & $3(21.4)$ & $6(42.8)$ & \\
\hline
\end{tabular}

Response was determined according to the EORTC/MSG criteria.

"Fisher's exact test for treatment success and failure.

${ }^{\dagger}$ Prophylactic voriconazole use or duration of therapy $<6$ weeks. 


\section{Discussion}

During the study period of two years (July 2010 to June 2012) a total of 28 patients aged 18-years old or younger were administered voriconazole, and 14 of these patients received serum level monitoring. The serum levels of patients who underwent TDM showed inter- and intra-individual variability, demonstrating the difficulty of predicting pharmacokinetics and the need for concentration monitoring in the pediatric population. The incidence of adverse events was similar in both the TDM and non-TDM group, but voriconazole discontinuation due to these adverse events was lower in the non-TDM group. Adverse events presented as encephalopathy, blurred vision, and liver enzyme elevation, where both encephalopathy and liver enzyme elevation occurred more frequently in patients whose drug levels were in the toxic range. Furthermore, there was a higher clinical response rate at 6 weeks in the TDM-group where the patients were able to maintain an average of $67.0 \%$ of their serum levels within therapeutic range.

Through this study, it was clearly shown that monitoring serum voriconazole levels during administration in pediatric patients is vitally important in many aspects. Among patients that received voriconazole TDM, $53.1 \%$ of the levels were within the therapeutic range of $1.0-5.5 \mathrm{mg} / \mathrm{L}$, and $46.9 \%$ were above or below the therapeutic level. Many previous studies have shown treatment failure far more common in the toxic and sub-therapeutic levels of voriconazole in adults ${ }^{17-19)}$. With the high incidences of sub-therapeutic and toxic voriconazole serum trough levels in the patients within our study, we thought it critical to assess factors that may contribute to the high inter- and intra - individual variability of the serum voriconazole levels.

Previous studies have demonstrated that elimination of voriconazole in children is linear, while other studies show non-linear pharmacokinetics ${ }^{20-22)}$. There have also been reports of high inter-individual variability in serum levels of children receiving voriconazole $^{12,20,22)}$, and one factor behind such inconsistencies that can be applied to the patients in this study is the phenotype of CYP2C19. A large percentage of asians are CYP2C19 poor metabolizers ${ }^{23)}$, but in our study, the CYP2C19 genotyping was not done. Furthermore, patients that have the same CYP2C19 genotype may have variable pharmacokinetics $^{17)}$, therefore it is more reasonable to monitor serum voriconazole levels and adjust the administered dosages rather than giving the patients fixed dosages.

For intra-individual variability, drug-interaction can be a factor affecting voriconazole serum level. Most patients in this study were administered many different types of drugs during the use of voriconazole, mostly in order to control the severe infection and manage their deteriorating underlying condition. In the TDM group, $79 \%$ of the patients received sulfamethoxazole/trimethoprim (increases voriconazole level), $57 \%$ of patients were administered with amphotericin B (decreases voriconazole level), and 36 $\%$ of patients received phenytoin (decreases voriconazole level ${ }^{15)}$. Midazolam, hydrocortisone, and ibuprofen are drugs that increase in toxicity when co-administered with voriconazole ${ }^{15)}$ and these drugs were administered concomitantly with voriconazole in $57 \%$ the patients. These findings are important in recognizing that drugs commonly administered to 
patients have drug interactions with voriconazole, but in most cases the drugs are given inevitably, therefore we must be aware of their effects on voriconazole serum levels.

Overall, the frequency of voriconazole-related adverse events within our study was similar or slightly higher compared to other studies ${ }^{17,19,21,24)}$. A previous case was reported of an adult patient presenting with visual and auditory hallucination during voriconazole treatment associated with high trough levels ${ }^{25)}$. Both patients that displayed voriconazole-related encephalopathy in our study had serum voriconazole levels in the toxic range for about three weeks, with one of the patient's serum level peaking up to $6.57 \mathrm{mg} / \mathrm{L}$, and the other 11.75 $\mathrm{mg} / \mathrm{L}$. Another study done by Imhof et $\mathrm{al}^{26)}$ found in an analysis of 28 treatment courses, that 6 patients presented with neurological adverse events, therefore emphasized the need for voriconazole TDM.

Both in the TDM and non-TDM group of our study, $57.1 \%$ of the patients $(n=8)$ had increased AST or ALT levels greater than 5-fold the baseline. When patients in the TDM group were investigated further to see the influence of toxic voriconazole levels on liver function, we observed that 6 of the 8 patients (75\%) with elevated AST or ALT had serum levels in the toxic range during the treatment. We also found that of these 6 patients, 4 had serum levels in the toxic range prior to AST or ALT elevation, showing the toxic effect of voriconazole on hepatic function. On the other hand, two patients' AST or ALT started to rise just before serum voriconazole levels measured in the toxic range. There may be a few explanations for this phenomenon, the first being the aggravation of liver function causing decreased metabolism of voriconazole, thus leading to higher serum levels. Another explanation may be that prolonged voriconazole use even in the therapeutic range may be hepatotoxic. Other studies have also found voriconazole to be hepatotoxic, the cause being multifactorial ${ }^{27,28)}$.

In both the TDM and non-TDM group, the rate of adverse events were similar, but two patients in the non-TDM group discontinued voriconazole due to adverse events, whereas none of the patients in the TDM group were held from treatment. Park et al. ${ }^{17)}$ investigated adult patients with IFI, and in their study, voriconazole TDM significantly reduced drug discontinuation due to adverse events. They speculated that the attending physician could continue voriconazole administration because adverse events were expected to be alleviated after dosage adjustment.

Most studies report a higher treatment failure rate in both toxic and sub-therapeutic levels of voriconazole ${ }^{17)}$, therefore we examined the difference in the outcome of patients within the TDM group depending on the percentage of voriconazole levels that remained within therapeutic range. In the TDM group, the patients were able to maintain an average of $67.0 \%$ of their serum voriconazole levels within therapeutic range during the first 6 weeks of treatment. But by the end of therapy, patients were only able to maintain an average of $45.5 \%$ of their levels within therapeutic range. We believe that this is one finding that answers why there was a high response rate at 6 weeks of treatment in the TDM group, but poor overall outcome. As the treatment duration extended, besides disease progression as a key factor in poor outcome, other factors may have contributed to the high variability in serum voriconazole levels; such as the increase in drug interactions, aggravated liver and kidney function, etc. 
We also sought the difference in the outcome between patients that received TDM versus those who did not. In the non-TDM group, 2 out of 14 patients (14.3\%) showed clinical and radiological improvement, whereas 8 out of 14 patients $(57.2 \%)$ in the TDM group showed improvement by 6 weeks. This shows that early efforts in trying to maintain voriconazole therapeutic level in patients lead to better clinical responses. Although the $P$-value yielded 0.055 showing less clinical significance, a greater sample size is likely to extrapolate clinically significant results. The final outcome, on the other hand, showed no clinically significant difference in the outcome among the two groups, where most of the patients' IFI aggravated $(P=0.664)$. The reason behind this is most likely due to the progression of the underlying disease of hematologic malignancy and prolonging immunocompromised state.

There were a few limitations in this study. First of all, there was some difficulty in deducing statistically significant findings because of the small study sample size, both in the analysis of the outcome and adverse events. Only 28 children with IFI at a single center were included, all with the same ethnicity. Secondly, because this was a retrospective study, there may have been a selection bias of the patients in the TDM and non-TDM group. Many of the patients who received monitoring of serum voriconazole levels had a more severe and unstable course, and the treatment duration lasted for a longer period. Another limitation in this study was determining to what degree the underlying conditions of the patients affected their voriconazole levels and frequency of side effects.

In conclusion, routine monitoring of serum voriconazole levels in pediatric patients with suspicious
IFI is strongly recommended for optimizing therapeutic response, especially as many factors contribute to the high variability in serum levels of children. Also, adverse events frequently occur during voriconazole administration, and monitoring serum levels allow physicians to continue treatment of IFI and avoid withdrawing the drug unnecessarily, enabling aggressive treatment for IFI.

\section{한 글 요 약}

\section{소아에서 보리코나졸 치료적 약물 농도 모니터링의 임상적 의의}

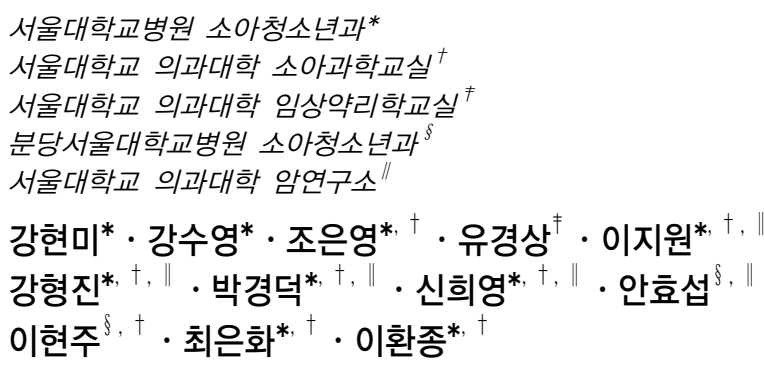

목적: 본 연구는 소아 환자들에서 voriconazole 치료적 약물 농도 모니터링의 임상적 의의를 분석하고자 하였다.

방법: 2010년 7월부터 2012년 6월까지 서울대학교병 원에 입원한 18 세 이하의 소아 환자들 중, 침습성 진균 감염증에 대해 voriconazole 치료를 받은 증례를 후향적 의무기록 분석을 통해 분석하였다. 본 연구에 포함된 총 28 명의 환자 중 14 명이 약물 농도 모니터링을 받았으며, 143 개의 혈중 농도 측정 값을 분석하였다. 모든 환자들에 게서 치료 효과 및 독성 증상 발현 여부를 파악하였다.

결과: 143 개의 혈중 농도 측정 값 중 $53.1 \%$ 에서 치료 적 범위 (1.0-5.5 mg/L) 내에 들었고, 같은 용법으로 치 료받았더라도 높은 혈중 농도 변동성 (high variability)을 보였다. 약물 농도 모니터링을 받았던 군(TDM 군)과 받 지 않았던 군(non-TDM 군)에서 각각 14 명 중 9 명 (64.3\%)이 독성 증상을 나타냈는데, TDM 군에서 신경 학적 증상 $(n=2,14.3 \%)$ 및 간기능 장애 $(n=8,57.1 \%)$ 
는 높은 voriconazole 혈중 농도 $(>5.5 \mathrm{mg} / \mathrm{L})$ 를 보인 환 자들에게서 나타났다. 반면, 시각 장애는 혈중 농도가 치 료적 범위 내에 있을 때 발현하였다 $(1.18 \mathrm{mg} / \mathrm{L}, 3.9 \mathrm{mg} /$ $\mathrm{L})$. TDM 군에서 non-TDM 군에 비하여 독성 증상으 로 인하여 약물을 중단했던 빈도가 낮았다 $(0.0 \%$ vs. $18.2 \%, P=0.481)$. 치료 시작 6 주 후 치료 효과를 분석 해본 결과 $\mathrm{TDM}$ 군의 $57.2 \%$ 에서 치료에 대한 반응을 보 였으나, non-TDM 군에서는 $14.3 \%$ 에서 치료 반응을 보 였다 $(P=0.055)$. 최종 치료효과 분석에서는 $\mathrm{TDM}$ 군의 $21.4 \%$ 에서 치료 반응을 보였으나, non-TDM 군의 14.3 $\%$ 에서 치료 반응을 보였다 $(P=0.664) . \mathrm{TDM}$ 군에서 치 료 시작 첫 6 주 동안 혈중 약물 농도를 분석했을 때 67.0 $\%$ 이상에서 치료적 범위 내에 들었으나, 치료 기간 전체 를 봤을 때에는 $45.5 \%$ 에서 치료적 범위 내에 들었다.

결론: 소아에서 voriconazole 사용 시 치료적 약물 농 도 모니터링을 통하여 치료 목표를 효과적으로 달성하고, 독성이 나타나는 것을 예방할 수 있다.

\section{Acknowledgement}

The authors would like to thank senior residents of Department of Clinical Pharmacology and Therapeutics, Seoul National University College of Medicine, Seokuee Kim, M.D. and Seonghae Yoon, M.D. for their expert opinion.

This study was supported by the Korean Society of Pediatric Infectious Diseases, underwritten by Novartis Korea in 2012.

\section{References}

1) Ascioglu S, Rex JH, de Pauw B, Bennett JE, Bille J, Crokaert $\mathrm{F}$, et al. Defining opportunistic invasive fungal infections in immunocompromised patients with cancer and hematopoietic stem cell transplants: an international consensus. Clin Infect Dis 2002;34:7-14.

2) Pfaller MA, Pappas PG, Wingard JR. Invasive fungal pa- thogens: current epidemiological trends. Clin Infect Dis 2006;43:S3-S14.

3) Ashley ESD, Lewis R, Lewis JS, Martin C, Andes D. Pharmacology of systemic antifungal agents. Clin Infect Dis 2006;43:S28-S39.

4) Herbrecht R, Denning DW, Patterson TF, Bennett JE, Greene RE, Oestmann JW, et al. Voriconazole versus amphotericin $\mathrm{B}$ for primary therapy of invasive aspergillosis. N Engl J Med 2002;347:408-15.

5) De Pauw B, Walsh TJ, Donnelly JP, Stevens DA, Edwards JE, Calandra $T$, et al. Revised definitions of invasive fungal disease from the European Organization for $\mathrm{Re}^{-}$ search and Treatment of Cancer/Invasive Fungal Infections Cooperative Group and the National Institute of Allergy and Infectious Diseases Mycoses Study Group (EORTC/MSG) Consensus Group. Clin Infect Dis 2008; 46:1813-21.

6) Kauffman CA. The changing landscape of invasive fungal infections: epidemiology, diagnosis, and pharmacologic options. Clin Infect Dis 2006;43:S1-S2.

7) Purkins L, Wood N, Ghahramani P, Greenhalgh K, Allen MJ, Kleinermans D. Pharmacokinetics and safety of voriconazole following intravenous- to oral-dose escalation regimens. Antimicrob Agents Chemother 2002;46:254653.

8) Walsh TJ, Karlsson MO, Driscoll T, Arguedas AG, Adamson P, Saez-Llorens X, et al. Pharmacokinetics and safety of intravenous voriconazole in children after single- or multiple-dose administration. Antimicrob Agents Chemother 2004;48:2166-72.

9) Lat A, Thompson III GR. Update on the optimal use of voriconazole for invasive fungal infections. Infect Drug Resist 2011;4:43.

10) Walsh TJ, Driscoll T, Milligan PA, Wood ND, Schlamm $\mathrm{H}$, Groll $\mathrm{AH}$, et al. Pharmacokinetics, safety, and tolerability of voriconazole in immunocompromised children. Antimicrob Agents Chemother 2010;54:4116-23.

11) Segal BH, Herbrecht R, Stevens DA, Ostrosky-Zeichner L, Sobel J, Viscoli C, et al. Defining responses to therapy and study outcomes in clinical trials of invasive fungal diseases: Mycoses Study Group and European Organization for Research and Treatment of Cancer consensus criteria. Clin Infect Dis 2008;47:674-83.

12) Neely M, Rushing T, Kovacs A, Jelliffe R, Hoffman J. Voriconazole pharmacokinetics and pharmacodynamics in children. Clin Infect Dis 2010;50:27-36.

13) Pascual A, Calandra T, Bolay S, Buclin T, Bille J, Marchetti $\mathrm{O}$. Voriconazole therapeutic drug monitoring in 
patients with invasive mycoses improves efficacy and safety outcomes. Clin Infect Dis 2008;46:201-11.

14) National Cancer Institute; March 20, 2013 [cited 2013 July 05]. 4.0:[Available from: http://ctep.cancer.gov/ protocol Development/electronic_applications/ctc.htm].

15) Taketomo CK, Hodding, JH, Kraus DM. Pediatric Dosage Handbook, 16th ed. Hudson, Ohio, Lexi-Comp, Inc.; 2009:1274-6.

16) Singh N. Treatment of opportunistic mycoses: how long is long enough? Lancet Infect Dis 2003;3:703-8.

17) Park WB, Kim NH, Kim KH, Lee SH, Nam WS, Yoon $\mathrm{SH}$, et al. The effect of therapeutic drug monitoring on safety and efficacy of voriconazole in invasive fungal infections: a randomized controlled trial. Clin Infect Dis 2012;55:1080-7.

18) Troke PF, Hockey HP, Hope WW. Observational study of the clinical efficacy of voriconazole and its relationship to plasma concentrations in patients. Antimicrob Agents Chemother 2011;55:4782-8.

19) Ueda K, Nannya $Y$, Kumano K, Hangaishi A, Takahashi $\mathrm{T}$, Imai $\mathrm{Y}$, et al. Monitoring trough concentration of voriconazole is important to ensure successful antifungal therapy and to avoid hepatic damage in patients with hematological disorders. Int J Hematol 2009;89:592-9.

20) Choi SH, Lee SY, Hwang JY, Lee SH, Yoo KH, Sung $\mathrm{KW}$, et al. Importance of voriconazole therapeutic drug monitoring in pediatric cancer patients with invasive aspergillosis. Pediatr Blood Cancer 2013;60:82-7.

21) Soler-Palacin $P$, Frick MA, Martin-Nalda A, Lanaspa M, Pou L, Rosello E, et al. Voriconazole drug monitoring in the management of invasive fungal infection in immunocompromised children: a prospective study. J Anti- microb Chemother 2012;67:700-6.

22) Michael C, Bierbach U, Frenzel K, Lange T, Basara N, Niederwieser D, et al. Voriconazole pharmacokinetics and safety in immunocompromised children compared to adult patients. Antimicrob Agents Chemother 2010; 54:3225-32.

23) Shimizu $T$, Ochiai $H$, Asell F, Shimizu H, Saitoh R, Hama $\mathrm{Y}$, et al. Bioinformatics research on inter-racial difference in drug metabolism I. Analysis on frequencies of mutant alleles and poor metabolizers on CYP2D6 and CYP2C19. Drug Metab Pharmacokinet 2003;18:48-70.

24) Solis-Munoz P, Lopez JC, Bernal W, Willars C, Verma A, Heneghan MA, et al. Voriconazole hepatotoxicity in severe liver dysfunction. J Infect 2013;66:80-6.

25) Kim M, Youn H, Kim SB, Cho YH, Lee M, Cho $S$, et al. A case of visual and auditory hallucinations during intravenous voriconazole therapy. Infect Chemother 2011;43:421-4.

26) Imhof A, Schaer DJ, Schwarz U, Schanz U. Neurological adverse events to voriconazole: evidence for therapeutic drug monitoring. Int J Infect Dis 2006;10:S61.

27) den Hollander JG, van Arkel C, Rijnders BJ, Lugtenburg PJ, de Marie S, Levin M-D. Incidence of voriconazole hepatotoxicity during intravenous and oral treatment for invasive fungal infections. J Antimicrob Chemother 2006; 57:1248-50.

28) Levin $M-D$, den Hollander JG, van der Holt B, Rijnders BJ, Van Vliet M, Sonneveld P, et al. Hepatotoxicity of oral and intravenous voriconazole in relation to cytochrome P450 polymorphisms. J Antimicrob Chemother 2007;60:1104-7. 